\title{
AGGREGATIVE VALUATION OF MASS TORT CLAIMS
}

\author{
Kenneth S. Abraham* and Glen O. Robinson**
}

\section{Introduction: Managerial Necessity in Mass Tort Cases}

Mass tort claims have added new burdens to a tort system that by many accounts is already strained by run-of-the-mill accident, product defect, and medical malpractice cases. With the new burdens have come more complaints about the performance of the tort system generally, and more proposals for its reform. That few of the complaints or proposals are new is unremarkable. The outpouring of critiques over the past thirty years has been such that the appearance of a significant new idea would be cause for considerable surprise-and even suspicion-on the common sense notion that if the proposal were really sound, it would have been discovered earlier.

This is not to say that the mass tort phenomenon has not generated some useful information on and insights into both the workings and the limitations of the tort system. Of particular value is the information that mass tort claims have provided about practical claims administration. The academic literature on tort law has tended to focus heavily on theoretical and doctrinal issues, to the relative neglect of practical issues of claims administration. These practical issues traditionally have not been of large concern to tort scholars mainly because, in the ordinary accident case, the details of paying judgments are matters of ministerial routine, determined by the court or by the parties without reported dispute or formality. Even when there are multiple plaintiffs or defendants, these management details usually have not posed important theoretical or practical problems of the kind noticed in legal scholarship.

The advent of large-scale mass tort claims, however, represented most importantly by the asbestos, Agent Orange, and Dalkon Shield cases, has shifted attention to the management side of tort claims. ${ }^{1}$ For the most part, the theoretical and doctrinal issues in these cases are familiar to the tort system from traditional, and frequently quite ordinary, cases. Admittedly, the causation problems in some of the mass tort cases have been unusually

Copyright (C 1990 by Law and Contemporary Problems

* Class of 1962 Professor of Law, University of Virginia.

** John C. Stennis Professor of Law, University of Virginia.

We thank Ian Ayres, Lynn Baker, Charles Goetz, John Monahan, John McCoid, Jeffrey O'Connell, David Rosenberg, George Rutherglen, Peter Swire, Laurens Walker, and participants in a workshop at the University of Virginia for helpful comments and discussion.

1. For extensive explorations of the management side of mass tort litigation, see generally Francis E. McGovern, Resolving Mature Mass Tort Litigation, 69 BU L Rev 659 (1989); Francis E. McGovern, Toward a Functional Approach for Managing Complex Litigation, 53 U Chi L Rev 440 (1986). 
difficult, involving issues of fundamental scientific uncertainty. In the asbestos and Agent Orange cases, for instance, the necessary reliance on epidemiological evidence has introduced a new complexity not found in conventional accident cases. Yet this characteristic does not distinguish mass tort claims. The causation issue in the Dalkon Shield litigation is fundamentally the same as that in many product liability or medical accident cases. ${ }^{2}$ Trite though it may be to observe, the distinguishing feature of most mass tort claims lies in the number of claims and the cost of adjudicating such claims within the traditional common law framework of individualized adjudication.

It also warrants notice that use of the single phrase "mass tort" obscures a huge difference between two classes of cases. The first class contains cases in which the number of claimants is between a few hundred and several thousand. In the past decade, there have been roughly a dozen such cases, including the MGM Grand Hotel fire litigation, ${ }^{3}$ DES suits, ${ }^{4}$ toxic shock syndrome cases, ${ }^{5}$ the Bendectin litigation, ${ }^{6}$ and the Hyatt Regency Hotel skywalk litigation. ${ }^{7}$ The second class contains the cases involving hundreds of thousands of claimants. There have been only three such mega-tort actions: the Agent Orange, Dalkon Shield, and asbestos litigation. ${ }^{8}$ This latter class of cases presents a critical problem for the tort system. As difficult as it has been to handle the former class of cases, traditional processes can do so after a fashion. In contrast, conventional methods of processing tort suits are wholly inadequate to handle hundreds of thousands of claimants. The logistics of mass claims administration dictated that something be done to make processing such claims manageable, and legal ingenuity has responded, developing distinctive processes for each setting.

To date, Agent Orange, Dalkon Shield, and asbestos are the only cases in which there was simply no choice but to employ special claim processes. However, partly by osmosis, and partly because of the sense that gains could be had from employing special claim processes even when doing so was not an undeniable necessity, similar approaches have been adopted in a number of the smaller mass tort cases as well. Although there is much to be said for engaging in such experimentation, the time has come for a more conscious examination of the premises that lie behind the adoption of special procedures for processing mass tort claims. In our view, these premises are

2. See Kenneth R. Feinberg, The Dalkon Shield Claimants Trust, 53 L \& Contemp Probs 79 (Autumn 1990).

3. In re MGM Grand Hotel Fire Litigation, $570 \mathrm{~F}$ Supp 913 (D Nev 1983).

4. For example, Sindell v Abbott Labs., 26 Cal 3d 588, 607 P2d 924 (1980).

5. For example, Kehm v Proctor E Gamble Mfg. Co., 724 F2d 613 (8th Cir 1983).

6. See In re Bendectin Litigation, 857 F2d 290 (6th Cir 1988).

7. In re Federal Skywalk Cases, 97 FRD 380 (WD Mo 1983) (approving settlement). See also In re Three Mile Island Litigation, 557 F Supp 96 (MD Pa 1982).

8. These actions have involved, respectively, approximately $125,000,210,000$, and 340,000 claimants. In contrast, there have been approximately 2,000 DES claimants, 1,000 claimants associated with the fire at the MGM Grand Hotel, and 2,000 Bendectin claimants. See Am Bar Ass'n, Report of the Commission on Mass Torts 15e (1989). 
controversial and debatable. Accordingly, the move from employing special procedures when doing so is necessary to employing them whenever feasible is too important to escape careful analysis. In the following discussion, we analyze some of the obstacles to settlement of mass tort claims, and we propose a new mechanism-aggregative valuation of claims at trial-to help transform the process of adjudicating and settling mass tort claims.

\section{From Necessity to Virtue}

Until quite recently, the attention given to innovative techniques for handling mass claims in the judicial system has been focused on procedural mechanisms for centralizing jurisdiction over the claims. Consolidation of claims in class actions is one vehicle for such centralizing; ${ }^{9}$ consolidation of cases for pretrial processes and facilitating settlements is another. ${ }^{10}$ Both types of consolidation are important means of achieving efficiencies in the adjudication of mass claims. The mere consolidation of claims or cases, however, is only partially responsive to the problems presented by cases like the Agent Orange, Dalkon Shield, and asbestos actions. The central problem in all of these cases does not lie only in the resolution of the front-end questions of liability and general causation that consolidation is designed primarily to facilitate. Rather, the sticking point in these cases often lies in the back-end allocation of awards to individual claimants once liability and general causation have been established. Consolidation of claims by itself does little to solve this problem. Further innovation is plainly needed.

Until now, the focus of most of the innovation has been on managerial techniques for processing, evaluating, and settling claims, and on the use of alternative dispute resolution ("ADR") procedures for claims that do not settle. These techniques are fairly conventional and largely unexceptionable. All are limited, however, by the boundaries set by the parties themselves; none attempts to modify the basic process by which disputed claims ultimately are adjudicated. The architects of these techniques appear to have assumed that the conventional common law trial procedures for adjudicating disputes cannot be effectively changed in ways that would materially improve the

9. Courts have been resistant to class actions in mass tort cases because of differences among plaintiffs regarding individual causation and injury. See David Rosenberg, Of End Games and Openings in Mass Tort Cases: Lessons From a Special Master, 69 BU L Rev 695, 696 (1989). However, under the burden of mass tort cases, this attitude appears to be changing, and courts are becoming bolder about certification of classes for generic issues. See, for example, Jenkins $v$ Raymark Indus., 782 F2d 468 (5th Cir 1986); In re "Agent Orange" Product Liability Litigation, 100 FRD 718 (ED NY 1983).

10. In the federal courts, consolidation of cases within a particular district may be ordered under Rule 42(a) of the Federal Rules of Civil Procedure. Consolidation of cases in different districts may be ordered by the Judicial Panel on Multi District Litigation according to 28 USC $\$ 1407$. Consolidation of the Agent Orange cases, In re "Agent Orange" Product Liability Litigation, MDL No 381 (JPMDL May 8, 1979) (unpublished order), is probably the most noteworthy illustration of the manner in which such consolidation can be used not only for pretrial processes but also to facilitate settlement. 
disposition of individual claims when managerial or consensual techniques fail. If this is the assumption, it should not go unchallenged.

Some of the settlement techniques also offer hope for important reforms in the conduct of formal claims adjudication. Especially noteworthy is the use of statistical claims profiles in evaluating individual claims, a technique explored (in practice and in scholarship) by Francis McGovern ${ }^{11}$ and outlined by Kenneth Feinberg in his discussion of the Dalkon Shield Option 3 plan. ${ }^{12}$ Essentially the strategy is to promote settlement of claims by presenting information to the parties on the valuation of similar claims in prior settlements and/or adjudications. Such a profile provides an indication of the amounts paid, in judgment or settlement, to different categories of claimants. These categories are defined as functions of certain variables that affect liability and the severity and duration of a claimant's injury or illness. ${ }^{13}$ Of course, statistical valuation here is at least implicitly, if not explicitly, a function of both probability and payout. More precisely, it is the set of probabilities of different payouts ranging from zero (no liability or no injury) to some upper limit (liability and positive damages up to an amount where the probability of award approaches zero).

This settlement strategy assumes that rational parties are kept from reaching settlement primarily by their different valuations of a claim, and that these different valuations in turn reflect different predictions of the probability and size of an award if the case is adjudicated. The trick, then, is to reduce these disparate valuations, which can be done by presenting profiles of awards in similar cases to both sides. This can be viewed as an attempt to construct a "market value" for the claims. Since the sale of tort claims to third persons is prohibited virtually everywhere, the development of an objective market valuation for such claims is precluded. ${ }^{14}$ Absent a true claims market, statistical claims profiles constitute an alternative source of objective valuation.

Of course, the effectiveness of this "surrogate market valuation" is dependent on the parties having a genuine interest in settling the claim on the basis of market value. Where this is the case, the convergence of the parties' respective valuations is expected to produce settlement; parties will settle when the difference in their valuations is smaller than the expected cost of

11. McGovern, 69 BU L Rev 659 (cited in note 1); 53 U Chi L Rev 440 (cited in note 1). See also Mark A. Peterson, New Tools for Reducing Civil Litigation Expenses (RAND, 1983).

12. Feinberg, $53 \mathrm{~L} \&$ Contemp Probs at 107-09 (cited in note 2).

13. Francis McGovern has reported that in Jenkins $v$ Raymark Indus., 782 F2d 468 (5th Cir 1986), "fewer than ten variables accounted for $90 \%$ of the variation among case values." Francis E. McGovern, The Cycle of Mass Tort Litigation (Yale Program in Civil Litigation Working Paper No 122 , May 1990).

14. See Marc J. Shukaitis, A Market in Personal Injury Tort Claims, $16 \mathrm{~J}$ Legal Stud 329,329 (1987). Shukaitis proposes free assignability of claims. He argues that this would increase both the likelihood and amount of payment to victims, but this is by no means inevitable. As to the likelihood of payment, a market could, as Shukaitis notes, make it easier for plaintiffs to realize on a claim; however, market valuation would also discourage insubstantial claims that are pursued simply through ignorance of their "true" (market) value. A market valuation would also constrain plaintiffs' overvaluation of claims just as it would defendants' undervaluation. 
litigation. ${ }^{15}$ It is obvious, however, that whether parties litigate or settle is determined not merely by their respective valuation of the claim and the cost of the two options. Strategic considerations, including idiosyncratic preferences not measured by ordinary information about the market value of a claim, often play a large role in whether parties settle or litigate. ${ }^{16}$ It is notoriously true that defendants who face large exposure to multiple claims may adopt a strategy of litigating claims regardless of their individual value to discourage future claims or to encourage more favorable settlements. It is equally notorious that plaintiffs-more precisely, plaintiffs acting through their attorneys ${ }^{17}$-may hold out against settlement at fair value, choosing instead to play a lottery with litigation. In effect this choice reflects a preference, usually the attorney's preference, for risk: the small probability of a large payoff is preferred to the claim's expected value. Notice that if such strategic objectives defeat settlement efforts, they are just as likely to frustrate attempts to implement ADR inasmuch as ADR depends on consent.

This tendency of plaintiffs and their attorneys suggests that ways must be found to influence the strategic incentives of the parties. One obvious way to do so would be to change the underlying substantive law. For instance, limiting the amount of recoverable non-economic damages, such as pain and suffering or punitive damages, would surely reduce plaintiffs' incentive to play the lottery with claims. The possibility of jury awards in excess of the objectively expected value of the claim is most sharply reduced by excluding or limiting those items of damages that cannot be objectively measured and are most likely to be exaggerated by juror subjectivity. For the moment, however, we wish to set to one side changes in either liability or compensation rules in order to focus on evidentiary approaches that might reduce strategic behavior and thereby promote settlement.

\section{A. Claim Profiles as Evidence}

An important first step in promoting settlement would be to permit the claim profiles used in settling claims to be employed in formal adjudication as well. The most modest use would be to permit a profile to be introduced as statistical evidence that the trier of fact-a jury in virtually all of these casescould consider in evaluating the claim. These profiles would likely be constructed, under the auspices of the courts, by statisticians and other technically qualified experts under the direction of special masters. The profiles would be defined only by "legally relevant" factors: the

15. See, for example, McGovern, 53 U Chi L Rev at 483 (cited in note 1). For more detail on the basic model, see Richard Posner, Economic Analysis of Law $\$ 21.5$ (Little Brown, 3d ed 1986).

16. See Rosenberg, $69 \mathrm{BU} \mathrm{L} \mathrm{Rev} \mathrm{at} \mathrm{705-06} \mathrm{(cited} \mathrm{in} \mathrm{note} \mathrm{9).} \mathrm{On} \mathrm{the} \mathrm{role} \mathrm{of} \mathrm{strategic} \mathrm{behavior} \mathrm{in}$ settlement negotiations generally, see Robert Cooter, Stephen Marks \& Robert Mnookin, Bargaining in the Shadow of the Law: A Testable Model of Strategic Behavior, $11 \mathrm{~J}$ Legal Stud 225 (1982).

17. In mass tort cases, it is inevitable that plaintiffs' lawyers, representing large numbers of victims, will make settlement or litigation choices and that such choices will reflect their own preferences as much or more than those of their clients. Of course, a lawyer's personal valuation of each individual claim necessarily differs from that of the client to the extent it is only a part of a large portfolio of claims having different expected values. 
characteristics of claims or claimants that the finder of fact in any individual trial may consider in making determinations of liability, causation, and damages. For example, in cases in which the asserted basis of liability is the failure to warn of an unavoidably dangerous quality in a product, profiles might take into account variations in different claimants' independent knowledge of the dangerous properties of the product in question if data showed that such differences in information were correlated with variations in earlier awards and settlements. Similarly, in a toxic exposure case, such data might show that awards and settlements varied with the type of disease the plaintiff had contracted and with the probability that contracting different diseases was a result of exposure to a substance produced by the defendant. In such cases, it would be permissible to define profiles by reference to differences in the variation in the severity of the diseases as well as the causal probabilities of contracting these different diseases.

In contrast, it would be impermissible to define the profiles by reference to legally irrelevant factors such as the race, gender, or religion of the claimant, even if data revealed that differences among claimants in these respects actually had affected recoveries in earlier awards and settlements in the same litigation. Although any such differences would be captured by the data aggregated in a given profile, the profile would tend to average the differences, evenly distributing the effect of a legally irrelevant factor among all persons whose claims fit the profile. For example, black and white claimants falling within a particular profile would be entitled to the same award, notwithstanding that, other things being equal, blacks had recovered less (or more) than whites in the cases upon which the profile had been based. By using only legally relevant factors to define the profiles, the risk that legally irrelevant factors had affected the earlier awards and settlements would be distributed equally among all claimants within a particular profile.

Although employing claim profiles formulated in this manner may seem unconventional, the use of statistical evidence has become routine in modern tort cases on questions of liability, causal responsibility, and damages. For instance, epidemiological studies have been the acknowledged basis for establishing general causation in a number of toxic exposure cases. ${ }^{18}$ Such evidence is not only relevant but necessary in certain cases. ${ }^{19}$ Moreover, even in ordinary tort cases involving permanent injury, the calculation of future damages is heavily dependent on general statistics concerning, for example, life expectancy, economic earnings, and medical costs. In making each calculation, the trier of fact necessarily draws inferences from general statistical evidence on the value of a particular claim. Under our proposal, the

18. See Note, Causation in Toxic Torts: Burdens of Proof, Standards of Persuasion, and Statistical Evidence, 96 Yale L J 376, 379 (1986) (authored by Steve Gold).

19. See, for example, Brock v Merrell Dow Pharmaceuticals, Inc., 874 F2d 307, 313, modified, 884 F2d 166 (5th Cir 1989), cert denied, 110 S Ct 1511 (1990) (absence of conclusive epidemiological evidence fatal to claim that Bendectin caused birth defects); In re "Agent Orange" Product Liability Litigation, 818 F2d 187, 193-94 (2d Cir 1987) (summary judgment affirmance against nonsettiing plaintiffs based partially on absence of epidemiological evidence linking Agent Orange to injuries). 
trier of fact would draw the same kind of inference from the statistical evidence summarized in a claim profile. Of course, there are differences between the statistical evidence used in conventional tort cases and mass tort claim profile data. The most obvious difference is that the profiles do not represent any objective reality; rather, they are a collection of opinions (those of juries or settling parties in prior cases) as to the value of a particular type of claim, and, legally, they are hearsay opinions that are generally inadmissible into evidence.

We can quickly push aside the hearsay objection. The profiles are hearsay, of course, since they are comprised of what out-of-court declarants (juries or settling parties in other cases) have (implicitly) asserted to be the value of a particular type of claim. All statistical evidence generally is hearsay, however, insofar as it depends on the credibility of persons who put together the underlying observations contained in the statistics. Despite its status as hearsay, statistical evidence is routinely used either directly or as a basis for expert testimony. ${ }^{20}$

The more substantial objection to the introduction of the model profiles is relevance. The argument against admission is that the opinions of prior juries or settling parties as to the value of certain types of claims have no relevance to the particular claim before the court. In part this argument rehashes an old debate about the extent to which disputed issues in a particular case can be resolved by reference to general probabilities (reflected in statistics or simply in intuited generalities, such as in the case of res ipsa loquitur) or can be decided only on "particularistic evidence." More than enough has been written on this subject. ${ }^{21}$ It is enough for us to record summarily our view that the objections to probabilistic proof rest on an exaggerated distinction between general probability and "particularistic" evidence. In all but the simplest case, determinations about particular facts depend on inferences drawn from generalized knowledge and hence on general probability. In fact,

20. See, for example, Zippo Manufacturing Co. v Rogers Imports, Inc., 216 F Supp 670, 683 (SD NY 1963). Of course, there is no generic exception to the hearsay rule for statistical data as such, but such data is generally part of regularly kept records or learned writings for which exceptions are provided. See, for example, In re "Agent Orange" Product Liability Litigation, 611 F Supp 1223, 1240-41 (ED NY 1985). Such data also can be used by testifying experts without regard to its hearsay status provided it is of a type reasonably relied on by experts in the field. Id at 1245 . See generally Edward W. Cleary, ed, McCormick on Evidence chs 31-33 (West, 3d ed 1984).

21. Some idea of the fascination the subject of probabilistic proof has held for commentators can be gleaned from the nearly 600 pages devoted to it in Symposium, Probability and Inference in the Law of Evidence, 66 BU L Rev 377 (1986). See also Charles R. Nesson, The Evidence or the Event? On Judicial Proof and the Acceptability of Verdicts, 98 Harv L Rev 1357, $1358 \mathrm{n} 5$ (1985) (citing sources). This lavish attention has not discouraged further comment. See, for example, Daniel Shaviro, StatisticalProbability Evidence and the Appearance of Justice, 103 Harv L Rev 530 (1989). In the specific field of torts, the debate about probabilistic proof has centered on causation issues. See, for example, Glen O. Robinson, Multiple Causation in Tort Law: Reflections on the DES Cases, 68 Va L Rev 713 (1982); David Rosenberg, The Causal Connection in Mass Exposure Cases: A "Public Law" Vision of the Tort System, 97 Harv L Rev 849 (1984); Richard W. Wright, Causation in Tort Law, 73 Calif L Rev 1737 (1985). 
it is difficult to imagine how a mass tort case would be adjudicated without probabilistic inferences drawn from general data. ${ }^{22}$

To be sure, not all data are equally useful, not all probabilities equally strong, and not all permissible inferences equally relevant. Even acknowledging the general use of statistics and probabilistic proof to determine such questions as general causation (for example, asbestos causes mesothelioma), some will no doubt object that the disposition of similar tort claims by prior juries or parties is simply irrelevant to the disposition of any other claim. However, legal relevance is not a free-standing proposition of pure logic; it is always tied to an accepted convention or rule about what the basis for a legal claim should be. The relevance objection to the admissibility of claim profile data rests on the assumption that every claim is unique and that its value therefore must be determined without reference to the value of any other claim, no matter how similar.

Although this is a fairly conventional assumption about the way common law adjudications are supposed to work, it is not a sacred principle of the tort system or of the common law that every claim be completely independent of the results of other claims. Over a century ago, Oliver Wendell Holmes argued that courts should be permitted to crystallize, into more or less fixed rules of law, the accumulated findings of juries on certain commonly occurring issues. ${ }^{23}$ His notion has never taken hold in ordinary common law adjudication, in part because of the perceived variousness of common law claims and because of general concerns about invading the province of juries. Neither of these concerns seems very compelling in the context of mass claims adjudication. That we permit collective determinations of common legal and factual issues in class actions and in consolidated cases indicates that there is nothing sacrosanct about individualized adjudication. In the mass tort context, individual determinations are usually unavailable for plaintiffs; settlement therefore is a practical necessity. Being relegated to settlement, these plaintiffs are also relegated to some form of aggregative claims valuation. The same conditions that preclude trial of most such claims also preclude individualized negotiation. The use of claim profiles would extend recognition of this imperative to formal adjudication.

Admittedly, transplanting statistical valuation from settlement to adjudication presents a conceptual problem not confronted in voluntary settlement. As statistical artifacts, the valuations aggregate determinations of liability, causation, and injury that are formally separate in adjudication. In ordinary adjudication, juries are not asked to determine the "value" of a claim

22. Our proposal contemplates that plaintiffs rest their case on manifest injury and not on mere risk of future injury. Analytically, measuring the expected value of a claim is the same for both types. In fact, even conventional, actual injury cases typically involve measuring probabilistic elements such as the extent of future damage. See Glen O. Robinson, Probabilistic Causation and Compensation for Tortious Risk, $14 \mathrm{~J}$ Legal Stud 779, 779-81 (1985). For present purposes, however, we make the simplifying assumption that the expected value calculation is for injuries that have become, in whole or in part, manifest at the time of suit.

23. See Oliver Wendell Holmes, The Common Law 98-99 (M. Howe, 1963; original ed 1881 ). 
on the basis of the claim's distinct elements; rather, they are asked first to determine whether the facts support liability, causal relationship, and injury, and, if so, then to proceed to value the injury. Profile valuations conflate these two types of determinations into a single question of valuation. This aggregation is not unfamiliar to juries, however, as they often informally mix these issues, for instance, by making adjustments in awards based on degrees of certainty about liability or causation. Moreover, it should be emphasized that we are dealing with the "back-end" of the mass tort case. The general questions of liability, or fault, and generic causation have already been determined for the general class of cases. While issues may remain concerning an individual plaintiff's own fault or contribution to her injury, the predominating factor in "back-end" controversies is the existence and amount of injury-a conventional valuation question.

A more serious difficulty is that developing reliable claim profiles could entail methodological difficulties that can be finessed in consensual settlement, where parties can make their own discount for any methodological infirmities they detect. One concern is that the profiles might be skewed by earlier parties' strategic choices in settling or litigating claims. Though this possibility cannot be overlooked, it is not a substantial obstacle to the use of claim profiles. Any strategic moves of one party can be checked by countermoves of the other. As repeat players, defendants would naturally have the greatest incentive (and ability) to engage in such moves. Sometimes, however, plaintiffs' lawyers are also repeat players because they represent thousands of claimants; then they too would have the incentive (and ability) to manipulate settlement or litigation of some claims for the benefit of others. Moreover, attempts to manipulate the database of the claim profiles are unlikely to be worth the effort unless the party can be assured of having a significant effect on the ultimate shape of the profiles. If the database is large, this would be difficult to accomplish. Recalling our market analogy earlier, one can think of the task as being roughly comparable to the conditions for setting prices in the market: a buyer/seller must have monopoly power or be a member of an effective and durable cartel in the "market" of relevant claims, or attempts to manipulate the market will fail.

Strategic concerns aside, skeptics will undoubtedly be able to identify other problems in constructing reliably representative claims data. For instance, mixing settlements and adjudicated awards in the data base might present a problem to the extent they contain different valuation biases. ${ }^{24} \mathrm{We}$

24. For instance, there is the possibility of a selection bias in the kinds of claims that are litigated which would also bias those valuations. Priest and Klein have argued that as the parties' estimates of the probability of the outcome approach the decision standard, the difference in their expected values of the claim increase, thereby making litigation more likely. See generally George L. Priest \& Benjamin Klein, The Selection of Disputes for Litigation, $13 \mathrm{~J}$ Legal Stud 1 (1984). The theory has prompted a controversy that we cannot pursue here. The implications of the theory for our purposes are not clear to us, since the Priest-Klein model deals with differences in probability estimates of outcome, not valuation.

Apart from the possibility of a Priest-Klein selection bias, jury valuations in adjudicated cases are likely to show greater dispersion than settlement values. However, settlement valuation should take 
cannot pursue these methodological problems further here. It is enough to note that questions of methodology would be the subject of a judicial hearing. We do not propose to allow every plaintiff to challenge the general features of the profiles; this would defeat the purpose of the exercise by threatening to transform every claim adjudication into a trial of statistical methods if not a game of jury confusion. Instead, courts should hold a separate hearing on all of the profiles in order to yield a definitive determination of the validity of methodology and general relevance to the classes of claims to which they will be applied. ${ }^{25}$ There is precedent for such a separate hearing on legal and general factual issues in mass tort cases. ${ }^{26}$

\section{B. Weighing the Evidence}

Once it is decided that statistical profiles can be considered by the jury, it becomes necessary to decide what weight may be given to them. If the profiles were considered simply as evidence, juries, in their (more or less) unfettered discretion, would be free to give the profiles such force as they considered appropriate. Leaving the jury wholly free to act on its discretion, however, would be somewhat at odds with our basic premise that unconstrained jury determinations produce excessive variation in claim valuations. In optimistic moments, we think that allowing juries to consider claim profiles might make juries more skeptical about apparently idiosyncratic claims. We cannot be confident, however, that self-enforced jury restraint would prevail. It may be useful, therefore, to consider giving the profiles special legal authority by making them presumptive of the value of each claim within the class to which the profile applies.

Giving rebuttably presumptive weight to profiles would be only marginally more radical than allowing them to be used simply as evidence. ${ }^{27}$ The

into account the full range of adjudicated valuations to the extent they have statistical significance. A more serious bias is that the settlement data will incorporate nuisance payments which, some might argue, should be excluded in using the valuations in court.

25. This is within the spirit of a more general, and more ambitious, suggestion by Walker and Monahan for establishing the authority of social research findings. See Laurens Walker \& John Monahan, Social Frameworks: A New Use of Social Science in Law, 73 Va L Rev 559 (1987). Although Walker and Monahan suggest that general social science findings can be introduced through independent judicial investigation and briefs from the parties, id at 588 , we assume that some kind of structured hearing would be required to review the claim profiles. We need not here consider whether this separate hearing would entail a jury. Although we are very skeptical about the value of a jury trial on highly technical issues of statistical validity, our principal concern is to have a single adjudication of generic issues of validity and class relevance.

26. See, for example, In re Bendectin Litigation, 857 F2d 290 (6th Cir 1988); Jenkins v Raymark Indus, $782 \mathrm{~F} 2 \mathrm{~d} 468$ (5th Cir 1986). We leave unanswered the question whether it would be possible to have a single hearing covering claims in different courts. Such a determination probably would not be within the ken of a federal court in which cases had been consolidated for pretrial proceedings under 28 USC \& 1407 . However, it should be possible to consolidate all the cases filed within a single district for purposes of such a hearing. In the case of bankrupt defendants (as in the case of Manville or A.H. Robins), the court with bankruptcy jurisdiction could make such a central determination.

27. Our use of a presumption here is roughly comparable to Walker and Monahan's proposal to have courts instruct juries on "social framework" information relevant to a particular adjudication. See Walker \& Monahan, 73 Va L Rev at 592-98 (cited in note 25). 
approach can be justified by the conventional criteria for the use of presumptions: a combination of probative power, judicial convenience, and public policy. ${ }^{28}$ The probative power of a specific claim profile would obviously depend on the soundness of the methodology, the depth of the database, and the quality of the analysis supporting it. We make no assertions about these factors in the abstract; as indicated above, they would all be subject to close judicial scrutiny in a special hearing. Judicial convenience would be enhanced to the extent that the use of presumptions generally discourages parties from using litigation as a lottery or for other strategic purposes. For instance, plaintiffs seeking to show that their claims fall outside the range of valuation shown by a particular profile would be put to a special burden of proof, which might or might not increase the cost of litigation but certainly would decrease the probability of success (that is, success in obtaining a recovery in excess of the "normal" value of their type of claim). There is also a correlative public policy rationale for employing a presumption in this context. That is, discouraging the strategic use of litigation is in the public interest. Moreover, insofar as use of the presumption tended to reduce variance in awards, the presumption would also promote the independent public policy value of evenhandedness.

We recognize that this last assertion is controversial. Aggregative valuation pits two policies against each other. On the one hand, the right to individualized treatment is a traditional feature of the common law system and one of its most valued characteristics. On the other hand, this same right also produces disparate outcomes that cannot be accounted for by intrinsic differences in the underlying claims. As noted above, critics have often remarked that the common law system of tort claims adjudication is an unprincipled lottery. ${ }^{29}$ Whether or not that characterization is completely accurate, it can hardly be denied that there is randomness in outcomes and that this randomness is in substantial degree a function of insisting that each claim be valued in isolation from any other. Any such randomness must be seen as a flaw in the system that undermines the system's accuracy and fairness. ${ }^{30}$

28. See Robinson, 68 Va L Rev at 731-32 (cited in note 21). A more numerous catalog of reasons appears in Edmund M. Morgan, 1 Basic Problems of Evidence 31-33 (ALI, 1954), but these reasons can be distilled into the above three.

29. See, for example, Jeffrey O'Connell, The Lawsuit Lottery: Only the Lawyers Win (Free Press, 1979); Stephen D. Sugarman, Doing Away With Tort Law, 73 Cal L Rev 555, 594 (1985); Marc A. Franklin, Replacing the Negligence Lottery: Compensation and Selective Reimbursement, 53 Va L Rev 774, 778 (1967). It is not academic critics alone who have complained of the chance element in tort litigation. Commenting on two jury verdicts in asbestos cases tried before him, a Philadelphia trial judge remarked that the verdicts made the litigation "more like roulette than jurisprudence." Quoted in Deborah R. Hensler, et al, Asbestos in the Courts: The Challenge of Mass Toxic Torts 42 (RAND, 1985).

30. The fairness objection rests on the venerable principle of treating like claims equally. What we describe as "accuracy" rests on the same principle. It is true, of course, that any aggregative treatment of claims can undermine accuracy in the sense of being insensitive to differences among individual claims, but it is important to understand that the present system is inaccurate in the other direction to the extent it implicitly recognizes differences that are either not grounded in objective reality or should not be recognized. Average values are not necessarily more appropriate or "true" 
Admittedly, the proposal that claim profiles carry a presumption is awkward. The basic idea would be to instruct juries to do two things: first, to determine which of the prespecified profiles most nearly represents the particular claim, and, second, to award damages equal to or within some defined interval around the median claim value ${ }^{31}$ of the relevant profile, unless the plaintiff or the defendant shows that the particular claim cannot be fairly represented by any of the profiles. Ordinarily, of course, the effect of such a presumption would be to impose on the party against whom it runs (in this case it would run against both parties) the burden of producing credible evidence to rebut the presumed fact. ${ }^{32}$ However, such an effect would not promote our aim of suppressing individualized determinations, whether on liability, causation, or damages. Given that the profile represents a class of claims, rebutting the presumption would require no more than the production of individualized evidence that would be routinely submitted anyway. In short, a simple rebuttable presumption in this context might have very little effect.

Nevertheless, the language of presumption might still be used to instruct the jury that it should adhere to the profile valuation absent some special showing that it is inappropriate for the particular claim. In effect, the jury would be instructed that the profile is to be used in evaluating the claim unless there is clear and convincing evidence that the plaintiff's claim is special. Strictly speaking, then, the "presumption" in this case is not a true presumption, in the sense of shifting the burden of production, but is rather a means of articulating a different standard of proof. However, the language of presumption is still suitable to suggest the effect of introducing a claim profile. Where appropriate, a court could enforce the presumption by overturning a jury's award. ${ }^{33}$

In principle at least, the effectiveness of this sort of presumption could be tested by observing the pattern of awards to see if it differs significantly from the profiles. If the profiles have the desired effect, claims falling clearly within the profiles would be settled more frequently than those in which the profile could be rebutted. Consequently-and somewhat counterintuitively-the more frequently awards at trial fell within the relevant profile, the less likely it

in some deep ontological sense. But in this context, average values can correct for extremes of distribution that are caused by the extremes of subjectivity.

31. Instructing the jury to restrict awards in this manner would force the jury to disregard extreme cases within the profile. If the profile were merely used as evidence, presumably the jury should consider the entire distribution of valuations contained in the claim profile. However, insofar as the purpose of the presumption here is to constrain jury discretion, that purpose could be undermined if juries were permitted to fix their awards at the extremes of the distribution contained in the profile.

32. Cleary, ed, McCormick on Evidence at 344 (cited in note 20).

33. It has been suggested to us that a judge might forewarn the parties that a jury award outside the profile would cause him to order a new trial. The purpose of such a communication would be to encourage last-minute settlement. However, we are somewhat skeptical of the value of promoting settlements after evidence is taken. What we are trying to develop is a rule that will signal to parties before trial and to juries at trial that awards deviating from some prescribed range of values will be accepted only in specially compelling cases. 
would be that the presumption was working effectively in promoting settlement. If no significant change in the pattern of jury awards were observed, it might be necessary to look for more radical means of conforming jury determinations to some collective valuation.

\section{Fixed Awards}

As long as settlement profiles are used only as evidence, or even as a rebuttable presumption of the value of plaintiffs' claims, our proposal may be seen as making only a modest change in the existing structure of mass tort claims administration. Under our proposal, the parties would be free to settle or not, and juries would have the same power as in conventional cases to make the award they considered correct. However, because profiles would be admitted into evidence and, under our stronger proposal, be rebuttably presumed a correct reflection of the value of the plaintiff's claim, the parties would be encouraged to reach a settlement governed by the relevant profile. Indeed, creating this incentive is an important purpose of the proposal, which is designed to promote voluntary settlement of individual mass tort claims.

Nevertheless, it would be disingenuous for us to claim that our proposal is merely a strategy for encouraging settlement. Although it undoubtedly will do just that, it would do so by altering both parties' substantive rights to the extent that the value of the asserted claim becomes more or less fixed by the profiles of other claims. The change in the parties' formal rights at trial also limits their freedom to reject settlement. Having come this far from traditional common law processes, it is natural to ask whether even more farreaching modification of the rules governing liability and damages in mass tort cases would be appropriate. For instance, if our aim of limiting jury discretion in making awards is sensible, why not further limit jury discretion? Our concern about the possible ineffectiveness of a rebuttable presumption could easily be solved by making claim profiles dispositive of individual claims. The rebuttable presumption then becomes a fixed schedule of damages-in effect an irrebuttable or conclusive presumption about the value of the plaintiff's claim. ${ }^{34}$ Under this further limitation, the jury's only job would be to determine which profile best represents a particular claim. Of course, such a complete collectivization of claims adjudication would radically change the common law system and would probably require legislative authorization. As this is written, a federal trial court in Texas (Judge Parker) has implemented such a collective scheme for a class of some 2300 parties, based on a trial of selected claims that represented the different disease categories into which the class had been divided. ${ }^{35}$ This is a bold, as well as

34. On damage scheduling in mass tort cases, see David Rosenberg, Damage Scheduling in Mass Exposure Cases, in 1 Courts, Health Science and the Law 335 (1991); damage scheduling in other tort cases is proposed by James F. Blumstein, Randall R. Bovbjerg \& Frank A. Sloan, Beyond Tort Reform. Developing Better Tools for Assessing Damages for Personal Injury, 8 Yale J Reg 171, 177-86 (1991).

35. See Cimino v Raymark Indus., Civ No B-86-0456-CA (ED Tex 1990). The court of appeals had issued a mandamus against a prior attempt at aggregative adjudication in the same case. In re Fibreboard Corp., 893 F2d 706 (5th Cir 1990). Undaunted by the setback, the trial court proceeded 
unique, experiment. However, the odds are against it being sustained on appeal or emulated by other courts.

Perhaps the most striking feature of a fixed valuation schedule of the sort we propose would be the difference in treatment between the early and later claims associated with the same mass tort. Of necessity the early claims would have to be resolved by current procedures, because there would be no previously resolved claims from which a set of claim categories could be constructed. Once a sufficient number of claims had been tried or settled, however, categories could be constructed and a fixed valuation schedule could be employed. Early claimants would be subject to the full panoply of conventional tort rights and constraints; decisions concerning liability, causation, and damages would be individualized. By contrast, later claimants' tort rights would be determined by the resolution of the earlier claims. Similarly, the rights and liabilities of the defendant (or defendants) would be conventionally "open" at the outset but subject to "closure" after a base of early claims had been categorized.

How can this difference in treatment be justified? The only apparent justification is an entirely practical and obvious one: in the absence of large numbers of resolved claims, there is insufficient data to support the creation of a fixed valuation schedule through the categorization of claimants and claims. Under this view, there can be no presumption, either rebuttable or conclusive, that the value of one claim is equal to the value of others in its category unless there are large numbers of resolved claims to which the claim can be compared. ${ }^{36}$

It might follow that there can be no departure from individualized adjudication through the use of aggregative or fixed valuation as long as the size and components of any given tort claim are dependent on characteristics unique either to that claimant or to the members of a group of similar claimants. However, if fixed valuations are acceptable when they are based on the resolution of an earlier set of similar claims, then the principle underlying individualized adjudication in any tort claim is called into question. Were it not for the absence of a set of previously resolved claims from which to create a fixed valuation schedule, it might make sense to subject the early claims to a fixed schedule of values as well. It may well be, then, that tort liability is imposed on an individual basis and damages are assessed individually simply because we have no other satisfactory way of doing so. Under this view,

with a revised plan, involving significantly more representative cases (a total of 160 ), but adhering to the same basic aggregative format. Defendants again sought mandamus, but this time a different panel of the Fifth Circuit refused to grant it. Appeal of the subsequent trial in Cimino is pending.

36. Thus, Francis McGovern's innovative approaches to the resolution of "mature" tort claims, see McGovern, 69 BU L Rev 659 (cited in note 1), require that there be such a base of claims before categorization can occur. David Rosenberg has proposed categorization as a matter of principle even before a body of claims has matured, but even his proposal extends only to mass claims. Rosenberg, 69 BU L Rev at 713-26 (cited in note 9). Of course, any kind of damage scheduling, for mass claims or conventional claims, entails practical problems of identifying a class of commensurable claims. See Peter H. Schuck, Scheduling Damages and Insurance Contracts for Future Services: A Comment on Blumstein, Bovbjerg and Sloan, 8 Yale J Reg 213, 217 (1991). 
individual adjudication of liability and damages becomes merely an unavoidable inconvenience rather then a principled requirement of the system.

Once the notion that individualized adjudication is required as a matter of principle has been called into question, the special treatment that mass tort claims has received also becomes problematic. The major argument for special treatment is entirely practical: restricting claimants' access to court, either through consensual or coercive methods, is expedient in mass tort cases because the judicial system would be overwhelmed if it were forced to treat mass tort claims like conventional, individual claims. It does not follow, however, that conventional claims should be privileged at the expense of mass claims. It is expedient to treat an avalanche of mass tort claims in a special manner because the judicial system does not anticipate them; when these claims are initiated, they seem special. But the processing burden these claims place on the courts is not unique; the claims are simply the latest to be filed. The burdens on the judicial system might be removed just as easily by subjecting all conventional claims to special procedures as a matter of course and permitting mass tort claimants unfettered access to individualized adjudication. No principle would preclude such a reversal of priorities. Only the difficulties of categorizing claims and applying fixed valuations in conventional cases and anticipating mass tort case loads would stand in the way. ${ }^{37}$

In short, for those who have surrendered the idea that principle requires individualized adjudication of either conventional or mass tort claims, adopting something like a conclusive presumption that like claims have equal value would simply be a problem of legal engineering. The main obstacle would be finding a model to use in awarding nonindividualized damages; that problem could be solved, however. For example, out-of-pocket losses usually can be proved easily and paid periodically to avoid most factual disputes. Assessing these losses would be "individualized," but nevertheless simple and uncontroversial. For obvious reasons, fixing pain and suffering damages would be a bit trickier. Assuming one were committed to compensating claimants for pain and suffering, ${ }^{38}$ however, it should be possible to construct some kind of valuation schedule indexed to the type of injury or to medical costs. In theory, the liability determination itself would have to be

37. For just this reason, we foresee equal protection and due process challenges to any substantially different treatment of mass tort and conventional tort claims, whether the treatment consists of different evidentiary rules or the more radical, institutional reforms suggested here. Of course, discriminating among victims of different classes of accidents lies at the heart of virtually all modern legislation in this area, from comprehensive schemes like workers compensation to partial reforms like automobile no-fault and medical malpractice reforms. Courts have generally had little difficulty finding a rational basis for the discrimination. See, for example, New York Central $R R v$ White, 243 US 188, 37 S Ct 247 (1917) (workers' compensation); Montgomery v Daniels, 38 NY 2d 41 , 378 NYS 2d 1, 340 NE 2d 444 (1975) (auto no-fault); Fein v Permanente Medical Group, 38 Cal 3d 137, 211 Cal Rptr 368, 695 P2d 665 (1985) (medical malpractice reform).

38. Virtually all proposals for substitute compensation schemes eliminate pain and suffering, in part because damages are difficult to schedule, but mostly to conserve insurance funds. 
adjudicated individually in conventional tort cases. Once uncertainty about the magnitude of a claimant's damages were removed, however, in practice there probably would be very few trials. At this point, consideration of the use of a conclusive presumption about a claimant's damages would merge with many of the proposals for general tort reform that have surfaced in recent years.

What would remain of the traditional cause of action in tort if this approach were adopted? The very notion of a tort action would simply be a name given to the process of paying compensation according to a schedule that bears only an attenuated relationship to the characteristics of particular claims. Although this compensation might be paid in a setting that was labelled "tort," in fact most of the characteristics that would identify that setting as "tort" would have disappeared. The question would then become whether these claims should disappear from courts of law as well.

\section{III}

\section{The Uses of Administrative Process}

A number of commentators have remarked on the similarity between the mass tort claims facilities described in this symposium and administrative programs. If the aggregative aims of these facilities were extended beyond settlement to claims adjudications as we have suggested, adjudication would come to resemble, mutatis mutandis, the administrative procedures used in Social Security disability and workers' compensation programs. At this point, the question arises whether the tort system would be so bureaucratized that it would make sense to remove mass tort claims, entirely or partially, from the courts.

Proposals to do just this are a venerable feature of the tort reform agenda, with an ancestry that goes back to the first workers' compensation schemes. Because most of these proposals have failed to gain acceptance, ${ }^{39}$ however, new social insurance programs such as the Social Security disability system ${ }^{40}$ typically supplement rather than supplant the common law tort system. Undaunted by this lack of past acceptance, advocates of administrative systems are finding fresh support for some such reform from their experience with mass tort claims. ${ }^{41}$

At the outset we need to examine whether and how to change, first, the substantive legal standards of liability and compensation, and, second, the

39. The most prominent example of the successful proposals are the auto no-fault plans adopted in fourteen states. Also at the state level, both Virginia and Florida have recently adopted no-fault programs to compensate the victims of birth-related neurological injury. See Va Code Ann $\S \S 38.2-5000$ to -5021 (Michie, 1990); Fla Stat $\$$ 766.301 to .316 (West, 1990). At the federal level, the Black Lung program, 30 USC $\$ \$ 901-45$ (1988), and the National Vaccine Program, 42 USC $\S 300$ aa-1-34 (Supp V 1987), are examples of such approaches.

40. For a description and analysis, see Jerry L. Mashaw, Administrative Justice (Yale U Press, 1983).

41. Sugarman, $73 \mathrm{Cal} \mathrm{L} \mathrm{Rev} \mathrm{at} \mathrm{596-603} \mathrm{(cited} \mathrm{in} \mathrm{note} \mathrm{29).} \mathrm{Compare} \mathrm{Kenneth} \mathrm{S.} \mathrm{Abraham,}$ Individual Action and Collective Responsibility: The Dilemma of Mass Tort Reform, 73 Va L Rev 845, 883-98 (1987) (analyzing the feasibility of creating a compensation fund for mass torts). 
processes by which the relevant standards are applied. The first issue entails far-reaching questions of social purpose, including questions concerning the goals of the tort system and its effects. In part we have already addressed this first issue in analyzing the possible use of claim profiles in adjudication. The second issue involves rather more limited, and more focused, instrumental questions of implementation. The two issues are obviously interrelated; for instance, a goal of corrective justice might be thought to imply a certain type of process for evaluating particular claims. ${ }^{42}$ Nevertheless, the second issue must be analyzed separately.

Specifically, that issue is whether and how administrative mechanisms might be used within the basic structure of the tort system, that is, within the framework of its essential functions. The settlement procedures discussed in this symposium are a step in this direction, as is our proposed extension of the aggregative valuation process to adjudicated cases. One might think of the basic design as being similar to the way in which administrative agencies determine the parameters of individual cases through the use of rulemaking. ${ }^{43}$ Perhaps the closest precedent from administrative law is the use of standardized criteria-the so-called "grid system"- - for determining disability under the Social Security disability program. ${ }^{44}$ The basic idea of using rules to delimit the scope of adjudicatory contests is not inherently more an attribute of the administrative process than the judicial process, however. For instance, the use of sentencing guidelines in federal criminal cases ${ }^{45}$ parallels the Social Security grid system and our proposed use of claim profiles.

More generally, the principle of stare decisis is based on the supremacy of rules over open-ended dispute resolution. Stare decisis, however, is only infrequently used, as courts are hesitant to use it to foreclose controversies in which litigants' claims appear to be distinctive. ${ }^{46}$ Still, this is as much the product of judges' cautiousness as it is an inherent principle of the judicial process.

Nevertheless, we must be wary of formalistic thinking about the judicial and administrative processes, or for that matter about courts and agencies. A claim does not belong in court merely because it looks more like a tort claim than any other conventional right to compensation. By the same token, we

42. This seems to be the implication of Ernest Weinrib's view of corrective justice. See Ernest J. Weinrib, Legal Formalism: On the Immanent Rationality of Law, 97 Yale L J 949, 974 (1988).

43. See, for example, United States v Storer Broadcasting Co., 351 US 192 (1956) (affirming the validity of this process against a challenge that it deprived individual parties their right to a hearing on the foreclosed issues).

44. See Heckler $v$ Campbell, 461 US 458 (1983) (sustaining Health and Human Services ("HHS") medical-vocational guidelines in disability cases against a due process challenge). The disability guidelines were directed to problems quite similar to those raised by mass tort claims; in addition to the management problem of disposing of huge numbers of individual claims, HHS was confronted with what it deemed unreasonable variation among administrative law judge determinations. Of course, the scale of the problem in the disability context is several orders of magnitude larger than in the torts context, the former involving several million claims per year.

45. See Mistretta v United States, 488 US 361 (1989) (affirming the constitutionality of the federal sentencing commission).

46. See, for example, Migues y Fibreboard Corp., 662 F2d 1182, $1187-89$ (5th Cir 1981). 
should not banish a set of claims from court merely because they do not look like conventional tort claims. As for mass tort claims, it is arguable that they do not belong with other tort claims because, at least in terms of numbers of claimants, mass tort claims are generally more akin to, for example, claims for black lung disease than conventional product accident cases.

There are three obstacles, however, to an approach that would relegate mass tort claims, such as the Dalkon Shield, Agent Orange, and asbestos claims, to administrative systems. As we cannot explore these obstacles, and possible ways to surmount them, in detail, we shall simply identify several of their salient aspects.

First, there is presently no all-purpose mass-accident claims agency to handle mass tort claims. The claims fall into the tort system not simply because we call them "torts," but because we have no other system with exclusive jurisdiction available to handle them. ${ }^{47}$ One solution would be to construct some kind of generic mass accident agency/system to deal with these problems as they arise. It is difficult, however, to visualize the contours of such a program without concrete information and experience produced by the emergence of the claims themselves. Even demarcating the general scope of such a program is problematic: what would qualify as a "mass accident"?

Second, the task of constructing an efficient and fair claims process for undefined future accidents is vexing. The history of mass tort actions teaches us that leaving claim determinations in the judicial system creates incentives for investigation that probably would be weaker in an administrative setting. Private attorneys representing their clients in successions of cases in the early stages of mass tort litigation involving the Dalkon Shield and asbestos were responsible for uncovering information relevant to both liability and causation that might never have emerged within another institutional structure. We would be reluctant to sacrifice the social benefits derived from these prospecting incentives. Nevertheless, it might be possible to continue to rely on the judicial system to make what we have called "front-end" determinations of liability and general causation, and then to transfer the "back-end" tasks of allocating compensation to an administrative agency. This bifurcation of responsibility would not necessarily compromise the positive incentives created by the tort system. The procedure created for arranging the transfer-for instance an order of a special judicial panelcould also provide for recognizing and rewarding the entrepreneurial contributions of attorneys. ${ }^{48}$

The question remains whether the agency would employ standards for resolving disputed claims that are the same as or different from those of the

47. Of course, many of the claims are handled non-exclusively by the tort system acting in tandem with such nontort systems as workers' compensation, Social Security disability, and health insurance.

48. This task need not be greatly different from current practice in judicial approvals of mass tort class action settlements. See In re "Agent Orange" Product Liability Litigation, 611 F Supp 1296, 1311-12 (ED NY 1985) (recognizing the need to create incentives to bring meritorious suits but cautioning that "contingency multipliers" should not be made in cases of borderline merit). 
tort system. We assume the standards employed in an administrative system would be somewhat different, simpler, and perhaps more focused on basic elements of compensatory need than those in the tort system. Without some such simplification, it is difficult to see the point of the transfer, for without simplified standards, the purely procedural differences between agency and court adjudications would probably not be enough to warrant the transfer.49

Third, even if a reformed mass tort claim processing agency were implemented, a satisfactory definition of its jurisdiction were developed, and the desirability of continuing to make front-end determinations in judicial proceedings were recognized, serious "switching" problems could arise. That is, the main technical problem is that it is by no means clear that the appropriate conditions for transfer could be specified in advance. The settlement facilities that have been used thus far to handle the back-end functions of claims determinations have been ad hoc structures designed to deal specifically with a defined set of cases.

Bifurcating adjudication would present more than mere technical problems. Eliminating the right to a jury trial on the individual damages claims also presents a serious constitutional issue. Complete displacement of the entire tort claim in favor of an administrative scheme presumably would be constitutional. ${ }^{50}$ However, retaining the basic tort action for generic issues while transferring the individual adjudication of damages to an agency might run afoul of the seventh amendment or its counterparts in state constitutions. $^{51}$ In fact, in a large sense, each sequence of moves we have outlined here can be viewed as a progressive sequence of limitations on jury prerogatives. ${ }^{52}$ However, we think it is only at the stage where the jury is

49. The principal difference is accounted for by the use of juries in court cases, and the evidentiary restrictions that attend jury use. However, as our proposed use of collective claims data suggests, jury trials can be made to resemble administrative adjudication.

50. The workers' compensation cases are the most directly relevant precedent. See, for example, Mountain Timber Co. v Washington, 243 US 219 (1917). Compare Atlas Roofing Co. v Occupational Safety and Health Review Comm'n, 430 US 442 (1977) (upholding nonjury adjudication of "public right" claims).

51. In Tull $v$ United States, 481 US $412,426 \mathrm{n9}$ (1987), the Supreme Court suggested that remedies in a civil case may not require jury determination. However, the fact that Tull involved a congressionally created action arguably distinguishes it from common law cases. See Granfinanciera, S.A. v Nordberg, $109 \mathrm{~S} \mathrm{Ct} 2782$ (1989) (distinguishing between "public right" and "private right" claims for purposes of determining the applicability of the seventh amendment). If the transfer of claims were to a federal agency-the most plausible scenario-Article III problems might also be raised under the precedent of Northern Pipeline Construction Co. v Marathon Pipeline Co., 458 US 50 (1982) (adjudication of common law contract claims by non-Article III judge unconstitutional). However, the Court's more recent decision in Commodity Futures Trading Commission $v$ Schor, 478 US 833 (1986) (upholding delegation of power to non-Article III agency to adjudicate state law claims), suggests to us that Article III would not be an important obstacle to such a transfer of adjudicatory authority.

52. Viewing jury discretion as the core problem, one may fairly ask (some of our colleagues have asked) why we should concentrate our attention on reforming adjudication of mass torts when the problem equally arises in all tort adjudication-indeed, reaches beyond tort law. Our answer, by way of confession and avoidance, is that juries may well present large problems throughout tort law, but the "jury problem," if we can call it that, is not a matter of equal concern across this entire domain. For present purposes, we think it is enough that juries create special difficulties in the resolution of 
bypassed, within a scheme that retains its common law character, that the constitutional question becomes important.

Constitutional questions aside, the transfer of individual claims adjudication to an agency would raise fairness concerns. Admittedly, as a practical matter, claims transferred to an administrative system would end up being treated very much as they are now treated by settlement facilities. Each forum would use the same aggregative methods. Nonetheless, the possibility, however theoretical, that a claim could be presented to a court may be important to the parties' perceptions of fairness. Of course, amending the courts' own traditional processes to incorporate aggregative methods of claims evaluation along the lines we have suggested may weaken the parties' preference for the judicial process. In other words, having compromised the system this far, it might become-logically it should become-a matter of indifference whether claims are determined by a court (jury) or an agency.

But logic does not count for everything. Even if our recommendations were accepted and much of the individualized adjudication so characteristic of conventional tort litigation were removed from mass tort actions, the allure of judicial supervision of the process would remain. Although an effective mechanism might eventually be constructed for switching back-end issues to an agency after resolution of front-end issues in court, the agency would lack the symbolic qualities that the courts-even when they are thrust into the role of bureaucrats-have managed to retain. ${ }^{53}$ It is difficult at this stage to say whether it would be worthwhile to compromise the judicial system at the backend to retain the virtues of adjudicating front-end issues in court. It is clear, however, that no shift of even the back-end issues from the courts to an agency could escape the concern for symbol that even the bureaucratization of mass tort litigation has not extinguished.

\section{Conclusion}

The stress mass tort litigation places on the legal system is not the only challenge posed by such litigation. In addition, the effort to fashion fair and effective methods of resolving mass tort claims has begun to call into question the assumptions that lie behind the legal system's approach to conventional tort claims. It is difficult to think about the proper role of mass tort claims facilities without also considering the proper scope of mass tort law itself. It is also difficult to think about the proper scope of mass tort law without considering whether the bureaucratization of adjudication that almost inevitably occurs in mass tort cases argues in favor of transferring at least

mass tort claims, difficulties that can be constructively addressed independently of other areas of the law.

53. These qualities include the right to have a decision made by a judge and jury, with all the formalities conventionally associated with judicial trials, as well as the opportunity to put defendants "in the dock" and require them to answer plaintiffs' charges. See Geoffrey C. Hazard, Jr., Authority in the Dock, 69 BU L Rev 469 (1989). 
some of the traditional functions of the courts in tort litigation to the administrative process.

In short, unless we know what we want a mass tort claims facility to accomplish, we cannot know how it should operate. Our proposals in this article are frankly provocative in their aim. They are intended to stimulate thinking about these aims and to sketch several methods that might loosen the constraints on mass tort claims facilities; it is not our ambition to formulate a definitive solution to all the problems of mass claims administration. Indeed, even thinking about these problems brings to mind Mark Twain's reminiscence on being instructed about the need to learn the contours of the Mississippi shoreline:

My boy, you've got to know the shape of the river perfectly. It is all there is left to steer by on a very dark night. . . Y You take a night when there's one of these grisly, drizzly, gray mists, and then there isn't any particular shape to a shore. A gray mist would tangle the head of the oldest man that ever lived. Well, then, different kinds of moonlight change the shape of the river in different ways. You see ....

Oh, don't say any more, please! Have I got to learn the shape of the river according to all these five hundred thousand different ways? If I tried to carry all that cargo in my head it would make me stoop-shouldered. ${ }^{54}$

54. Mark Twain, Life on the Mississippi 64-65 (Harper \& Row, 1917; original ed 1874). 


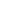

